IZA DP No. 7643

Party Membership and State Jobs in Urban China

Yuanyuan $\mathrm{Ma}$

Patrick Paul Walsh

September 2013

Forschungsinstitut zur Zukunft der Arbeit Institute for the Study of Labor 


\title{
Party Membership and State Jobs in Urban China
}

\author{
Yuanyuan Ma \\ University College Dublin \\ and IZA \\ Patrick Paul Walsh \\ University College Dublin \\ and IZA
}

Discussion Paper No. 7643

September 2013

\author{
IZA \\ P.O. Box 7240 \\ 53072 Bonn \\ Germany \\ Phone: +49-228-3894-0 \\ Fax: +49-228-3894-180 \\ E-mail: iza@iza.org
}

\begin{abstract}
Any opinions expressed here are those of the author(s) and not those of IZA. Research published in this series may include views on policy, but the institute itself takes no institutional policy positions. The IZA research network is committed to the IZA Guiding Principles of Research Integrity.

The Institute for the Study of Labor (IZA) in Bonn is a local and virtual international research center and a place of communication between science, politics and business. IZA is an independent nonprofit organization supported by Deutsche Post Foundation. The center is associated with the University of Bonn and offers a stimulating research environment through its international network, workshops and conferences, data service, project support, research visits and doctoral program. IZA engages in (i) original and internationally competitive research in all fields of labor economics, (ii) development of policy concepts, and (iii) dissemination of research results and concepts to the interested public.
\end{abstract}

IZA Discussion Papers often represent preliminary work and are circulated to encourage discussion. Citation of such a paper should account for its provisional character. A revised version may be available directly from the author. 
IZA Discussion Paper No. 7643

September 2013

\section{ABSTRACT}

\section{Party Membership and State Jobs in Urban China}

The "dual-track approach" for transition would have to be facilitated by an endogenous movement of workers away from the state into private jobs. Yet, using the Chinese Household Income Project Series (CHIPs) data for the year 2002, we document preferences and premiums for state jobs in urban China over private jobs. The state sector attracted the best workers in more favorable industries and regions and offered higher earning premiums. In addition, family party membership is found to be instrumental in allocating workers into state jobs which explains a good deal of the earnings differentials in terms of an endogenous state premium.

JEL Classification: J42, J62, O15, P23, R23

Keywords: labor mobility, earnings differentials, party networks, state jobs, urban China

Corresponding author:

Patrick Paul Walsh

SPIRe and Geary Institute

Newman Building

University College Dublin

Belfield, Dublin 4

Ireland

E-mail: ppwalsh@ucd.ie

\footnotetext{
* The authors acknowledge the Inter-university Consortium for Political and Social Research (ICPSR) for granting access to the CHIPS data. We also thank the participants in the CEA UK/Europe 2012 annual conference and the Development Roundtable in Geary Institute for helpful comments. We are responsible for all remaining errors.
} 


\section{Introduction}

Conventional wisdom often characterizes the transition path in China as a "dual-track approach" (Lau, Qian, and Roland 2000). Under the dual-track framework, one track is composed of inefficient traditional state-owned entities, while the other track represents new, basically market-oriented entities that should emerge in a parallel economy. Advocates of this dual-track approach expect a smooth phasing out of inefficient entities (especially the state-owned enterprises) following the introduction of non-state-owned entities (private and individual enterprises, foreign-invested enterprises, and other hybrids). The process assumes an endogenous movement of workers away from the state into private jobs. Workers would clearly have to understand their probability of getting a job in each sector, the wage return, and other benefits associated with the job in terms of health, pensions, and education. The assumption is that the private sector would have the edge in these respects. We do not believe this was the reality in the actual transition path that China embarked on, particularly up to 2002. In this paper, we challenge the conventional dualtrack model by investigating the nature of labor mobility between state and non-state jobs in urban China, for they are more homogenous in terms of job opportunities and access to welfare in urban China. .

The Eastern European transition to market economy experiences show that a sound non-discriminative national social security system was critical to induce restructuring and mobility of labor away from the state into the private sectors. This is illustrated in Burke and Walsh (2012), who undertake an analysis of this process for Poland in early transition. However, the Chinese experience tells a different story as a non-discriminative national social security system was not in place up to 2002.

Unlike the prediction of the conventional dual track model (Lau, Qian, and Roland 2000), the transition process in China simultaneously developed the state and private sector where the state remained the privileged and lead sector. Despite the enormous transition progress toward a decentralized market economy, the state sector in China still enjoys preferential treatment from the government.

The years between 1978 and 1992 form the preliminary exploratory stage of the 
transition. In the state sector, the pilot reform projects granting more autonomy to local authorities and managers are the main focus of this stage. The state sector gained huge efficiency by implementing factor inputs which are embedded with product-specific technologies facilitated by the reform granting more autonomy in this phase. For the private sector, before 1978, it was constrained or even forbidden to develop. ${ }^{1}$ During this phase, the private ownership and a pricing system outside the planned economy were allowed to develop, with a strong experimental flavor as they were regarded as a supplement to the state and collective sectors and playing a marginal, stopgap role in the national economy. ${ }^{2}$ The private sector employment started to grow.

The period from 1993 to 2003 witnessed the clear clarification of the relationship between "planned" and "market" elements. Institutional innovation gradually became the focus of reform in the state sector. The private sector was officially recognized and flourished. They both explored various ways of realization and started to cooperate with each other. However, the state sector still enjoyed the preferential treatment from the government and thus offered better payment packages to its workers (Xia, Song, Li, and Appleton 2013). Zhao (2002) finds that in 1996, earnings in the state-owned sector were significantly higher than in urban collective, private and individual enterprises and unskilled earnings in foreign-invested enterprises. In addition, workers often regard the state jobs as being more stable and secure due to their associated pension, housing, health insurance and other welfare benefits. Figure 1 shows the employment share in different ownership types in China from the year 1991 to 2002. ${ }^{3}$ Even in 2002, 25 years since the reform, the state sector still remained the dominant body of employment.

\footnotetext{
${ }^{1}$ Before the Third Plenum of the Chinese Communist Party's 11th Central Committee, the private sector was called the "Capitalist tail" that should be cut down, and it was considered as the root of evil behavior.

${ }^{2}$ The period of 1989 to 1991 witnessed a twist in the development of the private sector, because of the dispute over its nature -whether it is "socialist" or "capitalist".

${ }^{3}$ In 1991, about 70 percent of the employment was in the state sector, 24 percent in the urban collective units, 5 percent in the private and individual enterprises, and the rest in other forms of ownership. In 1995, around 65 percent worked in the state sector, 18 percent in the urban collective units, 11.8 percent in the private and individual enterprises, 3 percent in the foreign-invested enterprises, and rest in the other forms of ownership. By 2002, the employment in the state sector (including state-owned enterprises, government agencies, and non-government institutions) had declined by about 40.98 million, which is 36 percent of the whole workforce in 1995 and 57 percent of the 2002 workforce. In 2002, with only 28.9 percent working in the state sector and 4.5 percent in the urban collective units, there are over 20percent working in the private sector (both domestic and foreign).
} 


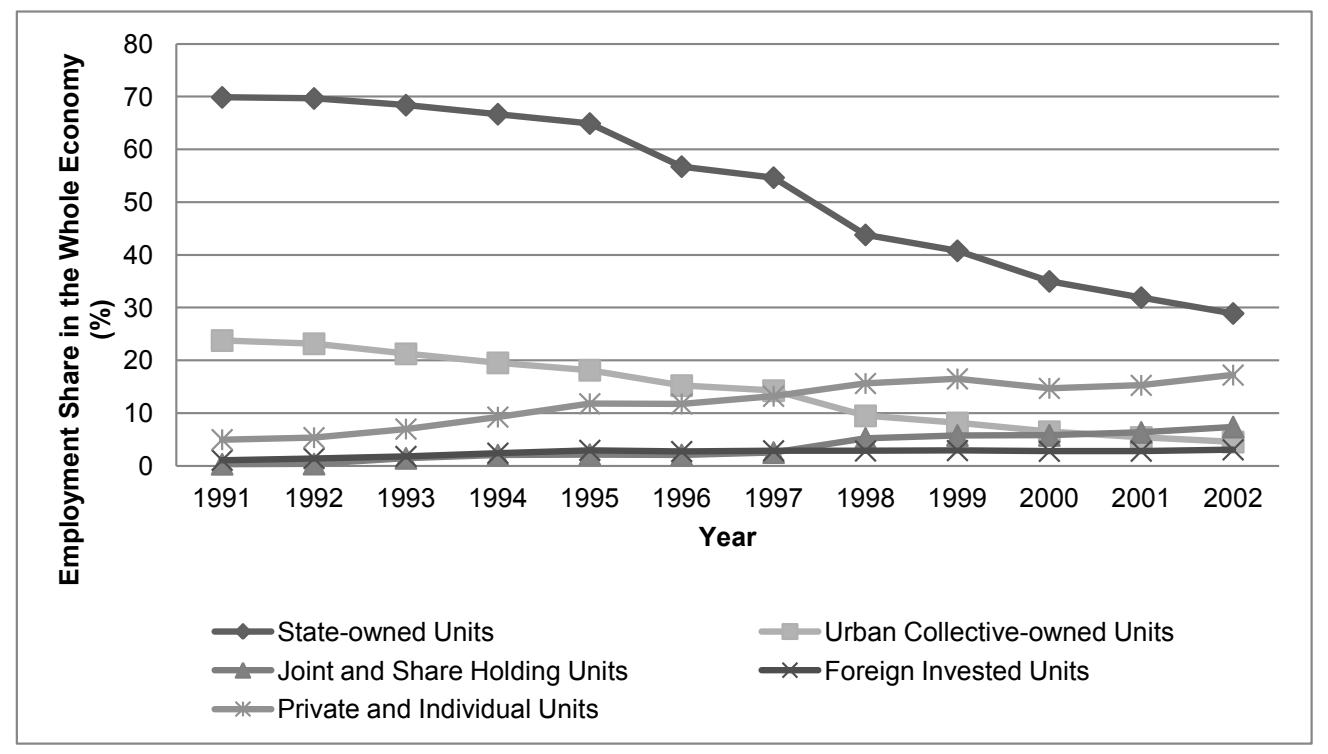

Figure 1: Employment Share in Different Ownership Types in China, (1991-2002)

Source: China Statistical Yearbooks.

After 2004, the establishment of the modern enterprise system, changes in the stateowned assets management, and the capital market reform pushed the reform into a new phase. Although the private sector has gained greater space for development, it is still struggling to acquire equal political and social support (around the establishment of business, exportation, and workers' social welfare, etc.) as the state sector. A more secure state-owned sector with extra benefits in kind ensures it remains quite attractive for job-seekers. Even in 2009, "topping the list of employment preferences are government jobs, which pay modestly but offer benefits and security. In 2008, some 750,000 students took the civil service exam, but only 2 percent could expect slots." 4

In this paper, we attempt to evaluate China's labor market transformation from the perspective of labor mobility between state and non-state jobs using additional family background/networking variables as instruments to identify causality. A thorough investigation would require a comprehensive analysis of the social and economic benefits associated with state or non-state jobs. We restrict our attention to the economic benefit of such a decision, which is the earnings differentials between the "state" and "non-state" jobs. ${ }^{5}$ Here, we define a state job as a job in a work unit that is dominantly controlled

\footnotetext{
${ }^{4}$ Li Hongmei, Finding a Job First before Seeking Preferences, China Daily, 2009-02-04. Available at: www.chinadaily.com.cn

${ }^{5}$ The "earnings" is defined as the sum of annual work-related earnings, including basic salary, bonus,
} 
by the state, including state-owned enterprises, government agents and institutions, and state share-holding enterprises in the dataset. The non-state sector includes urban collective enterprises, private and individual enterprises, foreign-invested enterprises, and other share-holding enterprises. ${ }^{6}$

The conventional dual track approach was intended to promote an endogenous movement of workers away from the state into private jobs. However, using the Chinese Household Income Project Series (CHIPs) data for the year 2002, we find that the stateowned sector still attracts the best workers in more favourable industries and regions. 7 In addition, family networks and party membership are found to be instrumental in allocating workers across state and non-state jobs which explain a good deal of the earnings differentials in terms of an endogenous state earnings premium. This reflects the fact that during the first 25 years of reform the state sector remained the privileged one and offered a better welfare package to workers. The regulation and social welfare package for families in the private sector jobs remained weak. This creates an inequality in society and a lack of investment and flow of human capital into the private sector.

The structure of this paper is as follows. Section 2 reviews the related literature. Section 3 introduces the data and methodology. Section 4 provides empirical results on our modeling of job selection and earnings differentials between state and non-state sectors. Section 5 further decomposes the earnings differentials to differences in endowments, returns, and selection. Section 6 provides robustness checks and further discussions. Section 7 concludes.

\section{Literature Review}

To our knowledge, our study is the first to analyze labor mobility and earnings differentials between state and non-state jobs in urban China taking into consideration family background/network in the selection process. The approach is related to the following literatures.

\footnotetext{
subsidies, other wages and other income in kind from the work unit.

${ }^{6}$ Detailed information on how we categorize the state and non-state jobs is available in appendix A.

${ }^{7}$ Detailed information on the dataset is available in section 3.
} 
There is a rich literature on China's economic transition from a planned economy to a market economy and the labor market outcome (Appleton et al. 2005; Griffin and Zhao, 1993; Riskin et al. 2001; Li 2008; and Tao 1999; Wu, 2009). Lau, Qian, and Roland (1997, 2000) develop a model to analyze the dual-track approach to market liberalization as a mechanism for implementing efficient Pareto-improving economic reform. Based on the continued enforcement of the existing plan while simultaneously liberalizing the market, they claim to provide a method for achieving Pareto improvement and efficiency at the same time. Opper (2001) summaries the experiences and lessons learned from the dual-track ownership reforms in China during the years 1978-1997. Our analysis suggests that reform induced the state sector to become efficient and privileged providing "good jobs" while the private sector hosted "bad jobs" without access to a good social security or tight regulation.

We empirically test for such preferences in workers in urban China. Apart from the individual demographics and job specific characteristics, parents' situation (including education, social status) may also affect one's job choice and earnings level. Family environment is widely believed to be a primary influence for children's outcome. Economists and social scientists have long been interested in intergenerational mobility, and documenting the persistence between parents and children's outcomes has been an active area of research. (Black and Devereux, 2010; Currie and Morretti, 2003)

There are certain mechanisms underlying this relationship. As noted in Solon (2004), children of wealthy parents earn higher incomes partly because they invest more in human capital and have more education. Besides, there may be genetic differences in ability that are transmitted from parent to child that lead to intergenerational persistence in income. Both differences in ability and human capital are well addressed in the literature. On the other hand, there is also a part in the intergenerational correlation that may be due to nepotism or the use of networks/connections.

Researchers in social sciences have long recognized the importance of social networks and patronage (Hunt et al. 2007; Faccio, 2006; Flinders 2009; Haughton 2008; Ioannides and Soetevent, 2006; Gordin, 2002; Katz and Shapiro, 1985; Mayntz and Derlien, 1989). 
The fact that many workers find jobs through friends and relatives is well documented (Montgomery 1991). In a survey of residents of a Massachusetts town, Granovetter (1973, 1995) finds that over 50 percent of jobs were obtained through social contacts. In a similar study, Rees (1966) finds numbers of over 60 percent. Since then, economists found similar figures for a variety of occupations, skill levels, and socioeconomic backgrounds in a large number of studies (Calvo-Armengol and Jackson, 2004).

There is also a rich literature on wage differentials between the public and private sectors across nations. Glinskaya and Lokshin (2005) investigate workers' wage differentials between public and private sectors in India and find a large public sector premium. Adamchik and Bedi (2000) document workers' wage differentials between public and private sectors in Poland and find a private sector wage advantage. There are other papers that look for a wage premium around union membership. Freeman and Medoff (1981) find that in US manufacturing, the percentage of workers organized had a strong positive association with the wages of union members but not with the wages of non-members, making the union wage differential a positive function of the extent of organization. In his definitive empirical work, H. Gregg Lewis (1986) finds that the overall impact of unions in the US was about 15 percent in the 1960s to the 1970s. Hirsch and his co-authors (2002) provide a series of evidence for decline in the wage premium for union membership since the mid-1980s.

\section{Data and Methodology}

\subsection{Data}

The data used come from the Chinese Household Income Project Series (CHIPs), which was conducted for the years 1988, 1995, and 2002 by the Chinese Academy of Social Sciences and National Bureau of Statistics. ${ }^{8}$ The aim of the survey is to measure the distribution of personal income, and related economic factors, in both rural and urban

\footnotetext{
${ }^{8}$ The Chinese Household Income Project is a joint research effort sponsored by the Institute of Economics, the Chinese Academy of Sciences, the Asian Development Bank, and the Ford Foundation. Additional support was provided by the East Asian Institute, Columbia University.
} 
areas in the People's Republic of China.

The samples cover 10 out of 31 provinces in 1988, 11 in 1995, and 12 in $2002 .^{9}$ We only use the third wave in 2002 in the main text, because it is the only wave with individuals' parents' information. In appendix B, we provide an analysis of all three waves and find that the rewarding system is quite persistent in the urban labor market, providing extra credibility for this cross-sectional analysis.

We use the urban resident subsamples, which only cover households and individuals with an urban registration card (Hukou). That is, we exclude those who are denied urban Hukou status, namely, the rural-urban migrant households. Although the migrant workers are indeed an important part of the urban labor market, we focus on the mobility of Hukou workers between state and private jobs in urban areas, as they are more homogenous in terms of job opportunities and access to welfare in urban China.

We restrict our sample to females aged 16-55 and males aged 16-60, since 55 and 60 are the legal retirement ages for female and male in China, respectively. We also exclude the owners of private or individual enterprises, since we cannot disentangle wages from profit in their cases.

We focus on examining the earnings differentials between the "state" and "non-state" jobs. While the state employees are comprised of state-owned enterprises, government agents and institutions, and state share-holding enterprises, the non-state employees include urban collective enterprises, private and individual enterprises, foreign-invested enterprises, and other share-holding enterprises. Workers in the "other" category are excluded due to ambiguity. ${ }^{10}$

In the same dataset (CHIPs) for the year 2002, there is a sub-dataset containing information about individuals' parents. We merged the datasets on a unique personal ID.

\footnotetext{
${ }^{9}$ For 1988, the 10 provinces include Beijing, Shanxi, Liaoning, Jiangsu, Anhui, Henan, Hubei, Guangdong, Yunnan and Gansu. Based on that, Sichuan province is added for year 1995 and Chongqing is added for year 2002 .

${ }^{10}$ There are 146 workers in "other" category in 1988, 61 workers in "other" category in 1995, and 238 workers in "other" category in 2002.
} 


\subsection{Methodology}

Based on Lee (1978) and Heckman (1979), in the first step, we examine whether there is specific selection preference for state jobs. In the second step, we estimate the impact of endogenous selection on the expected earnings of state and non-state workers in the urban labour market in China. Then, using the Oaxaca-Blinder decomposition method and its extensions, we estimate how the selection bias has affected the earnings differentials between state and non-state sectors and decompose the rest of the state premium into its deterministic factors.

In the Heckman two-step procedure, the first step is essentially a reduced form probit model of sector selection, modelling the probability of getting a job in a specific sector (state or non-state). In this step, we use the individual's demographics and parents' information to model the probability of getting selected into state or non-state sector, with controls for job-specific characteristics. In the second step, the estimation results of the probit model in the first step are used to construct a selectivity variable. Together with other variables, the selectivity variable is then used to estimate the earnings equation. The model looks like the following:

$$
\begin{gathered}
\operatorname{Pr}\left[y_{i t}^{*}>0\right]=\Phi\left(X_{1 i}^{\prime} \beta_{1}\right), \text { where } X_{1 i}^{\prime}=\left(F_{i}, J_{i}, D_{i}\right) \\
y_{2 i}=X_{2 i}^{\prime} \beta_{2}+\sigma_{12} \lambda\left(X_{1 i}^{\prime} \hat{\beta}_{1}\right), \text { where } \lambda\left(X_{1 i}^{\prime} \hat{\beta}_{1}\right)=\phi\left(X_{1 i}^{\prime} \hat{\beta}_{1}\right) / \Phi\left(X_{1 i}^{\prime} \hat{\beta}_{1}\right)
\end{gathered}
$$

$y_{i t}^{*}$ is a dummy variable we used as the dependent variable in step one, indicating whether individual i has been selected into a certain sector. $X_{1 i}$ is the vector of the explanatory variables (including individual's demographics, parents' information and additional controls for job characteristics) and $\hat{\beta}_{1}$ is the vector of all the estimates by probit regression of $y_{i t}^{*}$ on $X_{1 i}$ in step one.

In step two, we estimate $\lambda\left(X_{1 i}^{\prime} \beta_{1}\right)$ by $\lambda\left(X_{1 i}^{\prime} \hat{\beta}_{1}\right)$. The OLS regression of $y_{2 i}$ on $\lambda\left(X_{1 i}^{\prime} \hat{\beta}_{1}\right)$ and all the other regressors $X_{2 i}$ in step two, yields a semiparametric estimate of $\left(\beta_{2}, \sigma_{12}\right)$.

$y_{2 i}$ stands for the natural logarithm of annual earnings for individual i. The earnings variable is defined as the sum of annual work-related earnings, including basic salary, 
bonus, subsidies, other wages, and other income in kind from the work unit.

$X_{1 i}$ includes $F_{i}, J_{i}$, and $D_{i} . F_{i}$ is a vector of family background variables, including whether father/mother is alive; father/mother's ages (and the square term); father/mother's party membership; ${ }^{11}$ father/mother's education; ${ }^{12}$ father/mother's "Chengfen" (social status) classified in the time of land reform. ${ }^{13} J_{i}$ is a set of job characteristic controls, including occupation, ${ }^{14}$ industry, ${ }^{15}$ and city. $D_{i}$ stands for a set of demographic controls. $X_{2 i}$ contains the same set of variables as in $X_{1 i}$, except for the additional information on tenure at current job.

Tables 1, 2, and 3 present the summary statistics for the whole sample, the state sector sample, and the non-state sample, respectively. The tables indicate differences in earnings, individual characteristics, and family background between state and non-state jobs. The average earnings in state sector are higher. Figure C1 reports the earnings and wage distribution in state and non-state jobs for the year 2002, respectively. Figures C2 and C3 report the earnings distribution in various industries and provinces.

In general, state jobs offer a higher earnings level, while the difference in wages is not that prominent. This provides the motivation to use "earnings" as our variable of interest. There are more male and more members of the communist party in the state jobs. In addition, people tend to be older, more educated, and have a longer tenure in

\footnotetext{
${ }^{11}$ Here, party membership includes the membership of all the nine political parties in China. Besides the Communist Party Of China, there are Revolutionary Committee of the Kuomintang, China Democratic League, China Democratic National Construction Association, China Association for Promoting Democracy, Chinese Peasants' and Workers' Democratic Party, Zhigongdang of China, Jiusan Society, and Taiwan Democratic Self-Government League.

${ }^{12}$ It is a dummy variable, with 1 indicating father/mother has been schooled, and 0 meaning never schooled.

${ }^{13}$ There are 11 categories for "chegnfen (social status )": (1) poor peasant or landless; (2) lower middlepeasant; (3)rich-middle peasant; (4) rich peasant; (5) landlord; (6) manual worker; (7)office worker; (8) enterprise owner; (9) petty proprietor; (10) revolutionary cardre; (11) revolutionary armyman.

${ }^{14}$ There are eight occupation types, and they are (1) self-employed; (2) professional; (3) director of government agent, institution and enterprises; (4) department director of government agent, institution and enterprises; (5) clerical/office staff; (6) skilled worker; (7) unskilled worker; (8) salesclerk or service worker.

${ }^{15}$ There are fifteen industry types, and they are (1) Farm, forest, husbandry and fishery; (2) Mineral; (3) Manufacturing; (4) Electricity, gas and water supply facilities; (5) Construction; (6) Geological prospecting, irrigation administration; (7) Transportation, storage, post office and communication; (8) wholesale, retail and food services; (9) Finance and insurance; (10) Real estate; (11) Social services; (12) Health, sports and social welfare; (13) Education, culture and arts, mass media and entertainment; (14) Scientific research and professional services; (15) Government agents, party organizations and social groups.
} 
Table 1: Summary Statistics for the Whole Sample

\begin{tabular}{llll}
\hline \hline Variable & $\mathrm{N}$ & Mean & Std. Dev. \\
\hline Individual demographics & & & \\
Log(annual earnings) & 7535 & 9.28 & 0.62 \\
Age & 7558 & 42.62 & 7.31 \\
Male & 7558 & 0.56 & 0.49 \\
CPC membership & 7495 & 0.37 & 0.47 \\
Minority ethnicity & 7558 & 0.04 & 0.18 \\
Education & 7558 & 11.38 & 2.95 \\
Experience & 7558 & 6.18 & 8.65 \\
Tenure & 7558 & 16.44 & 9.63 \\
\hline Family Background & & & \\
Father alive & 7558 & 0.57 & 0.49 \\
Mother alive & 7558 & 0.72 & 0.44 \\
Father's age & 7556 & 67.12 & 10.42 \\
Mother's age & 7556 & 66.44 & 10.13 \\
Father's party membership & 7556 & 0.36 & 0.48 \\
Mother's party membership & 7556 & 0.1 & 0.29 \\
Father's education & 7556 & 0.85 & 0.36 \\
Mother's education & 7556 & 0.62 & 0.48 \\
\hline
\end{tabular}

Note: CPC stands for Communist Party of China.Here, party membership includes all the nine political parties in China.

Table 2: Summary Statistics for the State Sector Sample

\begin{tabular}{llll}
\hline \hline Variable & $\mathrm{N}$ & Mean & Std. Dev. \\
\hline Individual demographics & & & \\
Log(annual earnings) & 5442 & 9.38 & 0.58 \\
Age & 5457 & 42.85 & 7.38 \\
Male & 5457 & 0.58 & 0.49 \\
CPC membership & 5407 & 0.39 & 0.48 \\
Minority ethnicity & 5457 & 0.04 & 0.19 \\
Education & 5457 & 11.79 & 2.93 \\
Experience & 5457 & 5.3 & 8.03 \\
Tenure & 5457 & 17.7 & 9.24 \\
\hline Family Background & & & \\
Father alive & 5457 & 0.56 & 0.49 \\
Mother alive & 5457 & 0.72 & 0.45 \\
Father's age & 5455 & 67.18 & 10.53 \\
Mother's age & 5455 & 66.53 & 10.26 \\
Father's party membership & 5455 & 0.38 & 0.48 \\
Mother's party membership & 5455 & 0.1 & 0.3 \\
Father's education & 5455 & 0.84 & 0.35 \\
Mother's education & 5455 & 0.6 & 0.48 \\
\hline
\end{tabular}


Table 3: Summary Statistics for the Non-state Sector Sample

\begin{tabular}{llll}
\hline \hline Variable & $\mathrm{N}$ & Mean & Std. Dev. \\
\hline Individual demographics & & & \\
Log(annual earnings) & 1895 & 9.05 & 0.65 \\
Age & 1902 & 41.93 & 7.02 \\
Male & 1902 & 0.52 & 0.49 \\
CPC membership & 1890 & 0.19 & 0.39 \\
Minority ethnicity & 1902 & 0.03 & 0.15 \\
Education & 1902 & 10.26 & 2.75 \\
Experience & 1902 & 7.86 & 9.4 \\
Tenure & 1902 & 13.68 & 9.85 \\
\hline Family Background & & & \\
Father alive & 1902 & 0.56 & 0.49 \\
Mother alive & 1902 & 0.74 & 0.44 \\
Father's age & 1902 & 66.87 & 10.15 \\
Mother's age & 1902 & 66.15 & 9.16 \\
Father's party membership & 1902 & 0.29 & 0.45 \\
Mother's party membership & 1902 & 0.08 & 0.27 \\
Father's education & 1902 & 0.84 & 0.36 \\
Mother's education & 1902 & 0.62 & 0.48 \\
\hline
\end{tabular}

the state jobs. Meanwhile, more workers in the state sector have fathers who are party members.

\section{Empirical Results}

\subsection{Selection Process}

Table 4 reports the marginal effects of the first step of the Heckman two-step selection model for the state sector. Appendix $\mathrm{C}$ shows that the state jobs are more likely to reside in more favorable industries and regions. So we controlled for occupation, industry, and city-level regional differences in this model. Even after controlling for these factors, individual demographics and family background still significantly affect the selection process into state jobs. 
Table 4: Marginal Effects of the Probit Model

\begin{tabular}{ll}
\hline \hline & $\begin{array}{l}\text { Marginal } \\
\text { Effects }\end{array}$ \\
\hline$y_{i t}=1$ (if selected into a state job) & State=1 \\
\hline Individual demographics & \\
Age & 0.00396 \\
Age squared & 0.000142 \\
Gender & -0.0104 \\
Party membership & $.230^{* * *}$ \\
Ethnicity & 0.0485 \\
Education & $.0409^{* * *}$ \\
Experience & $-.447^{* * *}$ \\
\hline Family background & \\
Father alive & 0.0358 \\
Mother alive & -0.0318 \\
Father's age & 0.00343 \\
Mother's age & $-.0297^{*}$ \\
Father's age squared & $-3.06 \mathrm{E}-05$ \\
Mother's age squared & $.000252^{* *}$ \\
Father's party membership & $.165^{* * *}$ \\
Mother's party membership & 0.0804 \\
Father's education & 0.0823 \\
Mother's education & $-.125^{* * *}$ \\
Parents' chengfen dummies & yes \\
\hline Job characteristics & \\
City dummies & yes \\
Occupation dummies & yes \\
Industry dummies & yes \\
Constant & $1.499^{*}$ \\
Observations & 7,273 \\
\hline Note: $*$ denotes &
\end{tabular}

Note: $*$ denotes the significance level, with $* * *$ $\mathrm{p}<0.01,{ }^{*} * \mathrm{p}<0.05,{ }^{*} \mathrm{p}<0.1$. Here, experience is a dummy variable, with 1 indicating having working experience before current job. 
Father's party membership significantly affects one's possibility of getting employed in the state sector. If an individual's father is a member of the communist party or other legal parties in China, his/her probability of getting a job in the state sector is 16.5 percent higher than those whose father is not a party member. If we regard party membership as an indicator for network (or connections), as being a party member means being inside this party's network, it seems reasonable to argue that one's father's network may help an individual to enter a certain kind of network. Unlike the father, the mother influences her children mainly by her age and education, and the influence is much less significant than the father's impact. Therefore, we can say that family background does influence an individual's probability of being employed in the state jobs.

Being a member of the communist party is correlated with a higher probability of getting employed in the state sector. An extra year of schooling would also bring about 4 percent higher probability of entering the state sector.

After controlling for occupation, industry, and region, the selection into state jobs still is not a random process. More educated individuals with family connections are more likely to work in the state sector.

\subsection{State Premium}

In this section, we will test whether this selection process affects the actual earnings. We will also compare the estimates on earnings equations without and with correction for such selection process.

\subsubsection{State Premium without Correction for Selection Bias}

In this section, we perform an OLS estimation on equation (2) excluding the selectivity variable $\lambda\left(X_{1 i}^{\prime} \hat{\beta}_{1}\right)$. Instead, in the whole sample regression, we add a new dummy variable indicating the job sector, with 1 referring to being employed in a state job and 0 for being in a non-state job. 
Table 5: Estimation on Earnings Equation without Correction for Selection Bias

\begin{tabular}{llll}
\hline \hline Y=Log(annual earnings) & {$[1]$} & {$[2]$} & {$[3]$} \\
& $\begin{array}{l}\text { Whole } \\
\text { sample }\end{array}$ & $\begin{array}{l}\text { Non-State } \\
\text { sector }\end{array}$ & $\begin{array}{l}\text { State } \\
\text { sector }\end{array}$ \\
\hline Ownership type & & & \\
State sector & $.0814^{* * *}$ & & \\
\hline Individual demographics & & & \\
Age & .0138 & .00613 & $.0225^{*}$ \\
Age squared & -.000211 & -.000137 & $-.000304^{* *}$ \\
Male & $.142^{* * *}$ & $.202^{* * *}$ & $.116^{* * *}$ \\
Party membership & $.0824^{* * *}$ & $.106^{* * *}$ & $.0810^{* * *}$ \\
Minority ethnicity & .0261 & .0669 & .0230 \\
Education & $.0303^{* * *}$ & $.0272^{* * *}$ & $.0305^{* * *}$ \\
Tenure & $.00290^{* * *}$ & -.000536 & $.00432^{* * *}$ \\
Experience & .00508 & .00529 & .00263 \\
\hline Family background & & & \\
Father alive & $.0270^{*}$ & .0321 & .0228 \\
Mother alive & $-.0284^{*}$ & $-.0587^{*}$ & -.0181 \\
Father's age & .00394 & .00489 & .00463 \\
Mother's age & -.000218 & -.0118 & .00464 \\
Father's age squared & $-3.62 \mathrm{e}-05$ & $-3.28 \mathrm{e}-05$ & $-4.39 \mathrm{e}-05$ \\
Mother's age squared & $3.87 \mathrm{e}-06$ & $9.22 \mathrm{e}-05$ & $-3.46 \mathrm{e}-05$ \\
Father's party membership & -.00223 & -.00800 & -.00159 \\
Mother's party membership & .0212 & .0680 & .00297 \\
Father's education & .00284 & .0143 & -.00314 \\
Mother's education & .0193 & .0288 & .0166 \\
Parents' chengfen dummies & yes & yes & yes \\
\hline Job characteristics & & & \\
City dummies & yes & yes & yes \\
Occupation dummies & yes & yes & yes \\
Industry dummies & yes & yes & yes \\
Constant & $8.742^{* * *}$ & $9.485^{* * *}$ & $8.677^{* * *}$ \\
Observations & 7,273 & 1,883 & 5,390 \\
$R^{2}$ (adjusted) & .453 & .461 & .435 \\
\hline & & & \\
\hline
\end{tabular}

Note:* denotes the significance level, with ${ }^{* * *} \mathrm{p}<0.01,{ }^{* *} \mathrm{p}<0.05,{ }^{*}$ $\mathrm{p}<0.1$. 
Table 5 reports the estimation on earnings equations without correcting for the selection process for the whole sample and the split samples, controlling for different occupations, industries, and cities. Column 1 reports the estimates for the whole sample. Compared with the results in appendix B, we find that the ownership variable still stands out and the coefficients are very similar. We then split the sample into two groups: state and non-state sectors, to see whether the earnings setting mechanism is different for each sector.

Column 2 reports the estimates for the non-state sector, while column 3 reports the estimates for the state sector. Both estimates assume random job choice between state and non-state sectors. The results can be summarised as follows. Firstly, after controlling for individual demographic characteristics and job-specific characteristics, family background seems to have little significant impact on the actual earnings levels, except for small differences among different "Chengfen" groups.

Secondly, education matters for both sectors, but the returns for education are higher in the state sector. While an extra year of education gives about 2.7 percent premium in earnings in the non-state sector, the premium in state sector is about 3.1 percent, which is nearly 13 percent higher.

Thirdly, given years of work experience, tenure at current job significantly raises earnings in the state sector. An extra year of tenure at current job would increase earnings by approximately 0.4 percent. What is more, there is a positive reward for age in the state sector, while there is no such benefit in the non-state sector. Both of these facts may indicate the existence of a seniority effect in earnings setting in the state sector.

Fourthly, both gender and communist party membership significantly affect the earnings levels in both state and non-state sectors.

\subsubsection{State Premium with Correction for Selection Bias}

In this section, we perform estimates based on equation (2). Table 6 reports the second step results for the state and non-state sectors separately. ${ }^{16}$ Column 1 reports the

\footnotetext{
${ }^{16}$ The dependent variable in the first step is different for the non-state sector as for state sector. For the non-state sector, the dummy dependent variable equals to 1 if an individual is selected to a non-state
} 
second-step results of a Heckman two-step selection model for the non-state sector, while column 2 reports the counterparts for state sector. First and foremost, the coefficient for the selectivity variable $\lambda$ is significant in column 2 , but not significant in column 1 . This indicates that the previous conventional OLS estimates for the non-state sector are not seriously biased by sector selection, while the estimates for state sector are indeed biased by sector selection. Comparing column 1 here with column 2 in table 5 , we can find that the two models produce very similar estimates. Nonetheless, the evidence of selection bias in the state sector pushes us to use column 2 and table 4 together to explain the earnings setting mechanism in state sector.

Firstly, unlike the results without selection bias correction, family background does have a significant influence, and the influence is mainly reflected in the sector selection process as we see in table 4 . While father's party membership significantly affects one's possibility of getting employed in the state sector, it does not directly determine the actual earnings level afterwards. An individual's father's network may help him/her get inside a certain kind of network, but one's actual earnings level does not depend on this. So while family background does influence individual's earnings, it is mainly through its impact on individual's probability of being employed in the state jobs.

Secondly, being a member of the communist party not only correlates with a higher probability of getting employed in the state sector but also influences actual earnings afterwards. This may offer an explanation for the enthusiasm of young people for joining the Chinese Communist Party (CCP) nowadays.

Thirdly, education is significant in both stages. An extra year of schooling not only brings about 4 percent higher probabilities of getting into the state sector but also increases earnings by about 3.2 percent. Compared to the non-state sector, the state sector seems to reward education more.

job. For the state sector, the dummy dependent variable equals to 1 if an individual is selected to a state job. 
Table 6: Estimation on Earnings Equation Corrected for Selection Bias

\begin{tabular}{lcc}
\hline \hline Y=Log(annual earnings) & {$[1]$} & {$[2]$} \\
& Non-state & State \\
\hline Selectivity variable $(\lambda)$ & -0.0655 & $.129^{* *}$ \\
\hline Individual demographics & & \\
Age & 0.00656 & $.0226^{*}$ \\
Age squared & -0.000134 & $-.000297^{* *}$ \\
Gender & $.201^{* * *}$ & $.116^{* * *}$ \\
Party membership & $.116^{* * *}$ & $.0889^{* * *}$ \\
Ethnicity & 0.0702 & 0.0253 \\
Education & $.0288^{* * *}$ & $.0320^{* * *}$ \\
Experience & 0.00429 & 0.00161 \\
Tenure & 0.000222 & $.00504^{* * *}$ \\
\hline Family background & & \\
Father alive & 0.0343 & 0.0243 \\
Mother alive & $-.0598^{*}$ & -0.0193 \\
Father's age & 0.00494 & 0.00461 \\
Mother's age & -0.013 & 0.00341 \\
Father's age squared & $-3.34 \mathrm{E}-05$ & $-4.41 \mathrm{E}-05$ \\
Mother's age squared & 0.000103 & $-2.41 \mathrm{E}-05$ \\
Father's party membership & -0.00141 & 0.00461 \\
Mother's party membership & 0.0716 & 0.00477 \\
Father's education & 0.0172 & -0.00127 \\
Mother's education & 0.0243 & 0.0123 \\
Parents' chengfen dummies & yes & yes \\
\hline Job characteristics & & \\
City dummies & yes & yes \\
Occupation dummies & yes & yes \\
Industry dummies & yes & yes \\
Constant & $9.601^{* * *}$ & $8.441^{* * *}$ \\
Observations & 1,883 & 5,390 \\
\hline
\end{tabular}

Note:* denotes the significance level, with $* * * \mathrm{p}<0.01$, $* * \mathrm{p}<0.05,{ }^{*} \mathrm{p}<0.1$. 
Fourthly, age does not have a significant effect during the sector selection process, indicating no specific age preference during recruitment. But age does have a significantly positive effect on the earnings level afterwards, as does tenure. We observe positive and similar returns to older age and tenure to the results in the OLS estimation which pay no consideration to selection bias. This indicates the existence of a seniority effect.

Finally, after controlling for tenure, experience seems to have little impact on earnings level, while those who have work experience are less likely to work in the state sector. Together with the fourth observation, these provide evidence for the phenomenon that many young graduates (from high school or college) will acquire a job in the state sector immediately after their graduation. On the one hand, the state sector does not have a particular preference towards elders during recruitment-being young is not a disadvantage in recruitment. On the other hand, the existence of a seniority effect makes it rational to start one's tenure in the state sector as soon as possible.

\section{Decomposition}

The analysis in the previous section shows that both individual characteristics and family background play a role in the job selection process, and they all affect an individual's actual earnings. In this section, we further decompose the expected earnings differentials between state and non-state jobs with the help of Oaxaca-Blinder decomposition and other methods. We wish to estimate how the selection process affects the state premium, among other factors.

\subsection{Oaxaca-Blinder Decomposition}

The Oaxaca-Blinder decomposition is a standard technique used to understand the components of wage/earnings differentials between two groups (Oaxaca, 1973; Blinder, 1973; Oaxaca and Ransom, 1994, 1998, 1999; Bourguignon et al. 2008; Elder et al. 2010). We use "y" to denote the outcome variable of interest, which is the natural logarithm of individual's annual earnings in our case. And we have a vector of determinants "X" to 
explain y,

$$
\begin{gathered}
y^{\text {state }}=\beta^{\text {state }} X^{\text {state }}+\epsilon_{i}^{\text {state }} \\
y^{\text {nonstate }}=\beta^{\text {nonstate }} X^{\text {nonstate }}+\epsilon_{i}^{\text {nonstate }}
\end{gathered}
$$

Then, the gap between the mean outcomes $y^{\text {state }}$ and $y^{\text {nonstate }}$, is equal to

$$
E\left(y^{\text {state }}\right)-E\left(y^{\text {nonstate }}\right)=\beta^{\text {state }} X^{\text {state }}-\beta^{\text {nonstate }} X^{\text {nonstate }}
$$

where $X^{\text {state }}$ and $X^{\text {nonstate }}$ are vectors of explanatory variables for the state and non-state sectors, respectively. And we can further decompose the gap to

$$
E\left(y^{\text {state }}\right)-E\left(y^{\text {nonstate }}\right)=\Delta X \beta^{\text {nonstate }}+\Delta \beta X^{\text {nonstate }}+\Delta X \Delta \beta
$$

So that the gap in mean outcomes can be thought of as deriving from a gap in endowments (denoted by " $\left.\Delta X \beta^{\text {nonstate" }}\right)$, a gap in coefficients $\left(\Delta \beta X^{\text {nonstate }}\right)$, and a gap arising from the interaction of endowments and coefficients $(\Delta X \Delta \beta)$.

The "endowment effect" is associated with differences in the characteristics themselves. The "coefficients effect" is associated with differences in returns to individual characteristics across two groups, and it is often interpreted as a measure of discrimination in the literature.

Table 7 shows the decomposition results for estimations with and without the correction for selection bias. Without a correction, there is a significant mean earnings differential between state and non-state sectors. In urban China in 2002, the average annual earnings in the state sector was $11,825 \mathrm{RMB}$, while it was $8,578 \mathrm{RMB}$ in the non-state sector. There is a significant 3,247 RMB gap between those two sectors, which is almost 38 percent of the earnings in the non-state sector.

After controlling for the selection bias, there is still significant mean earnings differential between those two sectors, although the magnitude of the difference decreases. There is a significant 2,436 RMB gap between those two sectors, decreased by about 24 percent 
Table 7: Results of the Oaxaca-Blinder Decomposition

\begin{tabular}{lll}
\hline \hline Variables & {$[1]$} & {$[2]$} \\
& Overall & Adjusted \\
\hline \multirow{2}{*}{ Non-state sector } & $9.057^{* * *}$ & $9.098^{* * *}$ \\
& $(0.0154)$ & $(0.0922)$ \\
State sector & $9.378^{* * *}$ & $9.339^{* * *}$ \\
& $(0.00791)$ & $(0.0174)$ \\
Difference & $-.321^{* * *}$ & $-.241^{* * *}$ \\
& $(0.0173)$ & $(0.0938)$ \\
Endowments & & $-.306^{* * *}$ \\
& & $(0.0259)$ \\
Coefficients & \multicolumn{2}{c}{$-.117^{* *}$} \\
& \multicolumn{2}{c}{$(0.0578)$} \\
Interaction & $.182^{* *}$ \\
\multicolumn{3}{c}{$(0.0922)$} \\
Observations & 7,273 & 7,273 \\
\hline Note:Standard errors in parentheses.
\end{tabular}

compared to the gap before adjustment. Even still, the gap is 27.3 percent of the annual earnings in the non-state sector.

The decrease of the earnings gap between state jobs and non-state jobs can be attributed to the selection variable $\lambda$. About 24 percent of the expected raw earnings differentials are explained by the selection process into state jobs.

All the three effects are significant, with the highest significance level to endowments effect and the lowest significance level to the interaction effect. The endowment effect accounts for the bulk of the gap in earnings in two sectors.

The majority of the earnings differentials between state and non-state sectors in urban China can be attributed to the individuals' differences in their "endowments" (like individual demographics, family background, and job-specific characteristics), instead of different returns to the individual characteristics in different sectors. That is not to say that the state sector rewards individual characteristics differently, but rather the state sector attracts individuals with better endowments. ${ }^{17}$

\footnotetext{
${ }^{17}$ Here, individual demographic characteristics include individual's age, gender, party membership, education, experience, and tenure. Family background includes whether parents are alive, parents' age, parents' education, parents' party membership, parents' "chengfen" (social status), while the job-specific characteristics includes occupation, industry, and city.
} 


\subsection{Generalization and Extensions on Oaxaca-Blinder Decomposition}

The most used generalization and extensions of the Oaxaca-Blinder decomposition are suggested by Reimers (1983), Cotton (1988), and Neumark (1988). Consider Oaxaca's decomposition as a special case of the following decomposition:

$E\left(y^{\text {state }}\right)-E\left(y^{\text {nonstate }}\right)=\Delta X\left[D \beta^{\text {state }}+(I-D) \beta^{\text {nonstate }}\right]+\Delta \beta\left[X^{\text {state }}(I-D)+X^{\text {nonstate }} D\right]$

where I is the identity matrix and D is a matrix of weights. The first term is called the "explained part," which refers to the part explained by the differences of observed characteristics, while the second term is called the "unexplained part." The "unexplained part" refers to that part which cannot be explained by the observed characteristics, but by different treatment/returns to those characteristics. Hence, the "unexplained part" is also used to indicate the discrimination level in the literature.

When D equals 0 or 1 , it will be the two forms of Oaxaca decomposition. However, some other formulations have also been suggested. Reimers (1983) suggests weighting the differences in the Xs by the mean of the coefficient vectors. Cotton (1988) suggests weighting the coefficient vectors by the proportions in the two groups. Neumark (1988) makes use of the coefficients obtained from the pooled data regression.

Table 8 shows how the explained and unexplained portions of the earnings gap vary with different decomposition weights. The first and second columns correspond to the Oaxaca decomposition, with D equal to 0 or 1 . The third and fourth columns correspond to Reimers' and Cotton's decomposition, where the diagonal of D equals to 0.5 or 0.74. Despite various decomposition weights, it is the difference in the mean values of $\mathrm{X}$ that accounts for the majority of the difference in average annual earnings in the non-state and state sectors. Differences in the effects of the determinants play a comparatively much smaller part in explaining earnings differentials.

The majority of the earnings differentials come from the "explained part," which is the part explained by our model. So, the majority of the earnings differentials can be explained by our Heckman Selection model. Within the model, it is the endowments 
Table 8: Results of the Oaxaca-Blinder Decomposition

\begin{tabular}{lllll}
\hline \hline D: & 0 & 1 & $\begin{array}{l}0.5 \\
(\text { Reimers') }\end{array}$ & $\begin{array}{l}0.74 \\
\text { (Cotton's ) }\end{array}$ \\
\hline \% explained & 127 & 51.5 & 89 & 104 \\
$\%$ unexplained & -27 & 48.5 & 11 & -4 \\
\hline
\end{tabular}

Source: Author's calculation.

Table 9: Results of the Oaxaca-Blinder Decomposition

\begin{tabular}{llll}
\hline \hline & {$[1]$} & {$[2]$} & {$[3]$} \\
& Oaxaca & Reimers' & Cotton's \\
\hline Selection process & $24 \%$ & $24 \%$ & $24 \%$ \\
Individual characteristics & $25.90 \%$ & $32.00 \%$ & $28.90 \%$ \\
Job specific variables & $50.10 \%$ & $44 \%$ & $47.10 \%$ \\
Total & $100 \%$ & $100 \%$ & $100 \%$ \\
\hline
\end{tabular}

Source: Author's calculation.

effects that drive the earnings differentials. Therefore, this provides evidence to support our hypothesis that the majority of the earnings differentials between state and nonstate sectors in urban China can be attributed to the individuals' differences in their demographic characteristics, family background, and job-specific characteristics and not to different returns to the those characteristics in different sectors.

\subsection{Further Decomposition}

We find that it is the individuals' endowment that drives the earnings differentials between state and non-state jobs in urban China. In this section, we go a step further to calculate the exact contribution rate of each contributing factor: the selection process, individual demographic characteristics, family background, and job-specific characteristics.

Table 9 reports the contribution rate of each factor to the earnings differentials between state and non-state jobs in urban China. The first column shows the relative contribution rate in the Oaxaca decomposition. The second and third columns are the results in Reimers' and Cotton's decomposition methods. Despite trivial difference, all three decomposition methods showed that the selection process accounts for 24 percent of the earnings differentials in urban China. 


\section{Robustness Checks}

In this section, we report alternative model specifications to probe the robustness of the main results of this paper. We start by estimating the sample in the manufacturing industry only, the industry where the private sector is the most competitive. Then, we drop the family background variables in the second stage to see whether there will be significant changes in the estimates. This is to show how good an instrumental variable the family background/networking is. Finally, we estimate the sample in the most advanced cities where the private sector is the most competitive. In all of these alternative model specifications, we want to test if the state is still the preferred job giving a higher return in earnings.

\subsection{Manufacturing Industry}

The reasons for choosing the manufacturing industry sample are the following. Firstly, the manufacturing industry is among the group of industries where the private sector is the most competitive to the state sector, in terms of employment share. In CHIPs 2002, only 59.1 percent were state workers in the manufacturing industry, while most industries had more than 70 percent state workers. Secondly, among industries with the most competitive private sector, the manufacturing industry has relatively decent numbers of observations to conduct regressions. We have 2,078 observations in the manufacturing industry, about 28.6 percent of all observations. Detailed information on the share of state workers and number of observations in each industry is available in figure $\mathrm{C} 4$ and table $\mathrm{C} 1$, respectively.

Table 10 shows the results for the manufacturing industry. Column 2 reports the marginal effects from the first stage probit model, and column 1 reports the second stage results. The estimates are quite similar to our main results in tables 4 and 6 . First, the job assignment is not random. Family networks play a significant role in the job selection process. Second, the selection process itself has a significant effect on individual's actual earnings. 
Table 10: Heckman Two-step Estimates for the Manufacturing Industry

\begin{tabular}{|c|c|c|}
\hline & $\begin{array}{c}{[1]} \\
\text { 2nd-step results }\end{array}$ & $\begin{array}{c}{[2]} \\
\text { 1st-step results } \\
\text { State }=1\end{array}$ \\
\hline \multicolumn{3}{|l|}{ Individual demographics } \\
\hline Age & -0.0132 & $-.117^{* *}$ \\
\hline Age squared & 0.000118 & $.00153^{* * *}$ \\
\hline Male & $.155^{* * *}$ & 0.0704 \\
\hline Party membership & $.100^{* * *}$ & $.233^{* * *}$ \\
\hline Minority ethnicity & -0.0473 & -0.127 \\
\hline Education & $.0331^{* * *}$ & $.0443^{* * *}$ \\
\hline Experience & -0.000332 & $-.504^{* * *}$ \\
\hline Tenure & $.00982^{* * *}$ & \\
\hline \multicolumn{3}{|l|}{ Family background } \\
\hline Father alive & 0.019 & 0.0636 \\
\hline Mother alive & 0.0223 & -0.00461 \\
\hline Father's age & 0.00155 & 0.00154 \\
\hline Mother's age & -0.00982 & -0.0143 \\
\hline Father's age squared & $-1.44 \mathrm{E}-05$ & $-1.09 \mathrm{E}-05$ \\
\hline Mother's age squared & $7.96 \mathrm{E}-05$ & 0.000163 \\
\hline Father's party membership & 0.0524 & $.213^{* * *}$ \\
\hline Mother's party membership & -0.00216 & 0.0553 \\
\hline Father's education & 0.0141 & 0.00954 \\
\hline Mother's education & -0.0574 & $-.130^{*}$ \\
\hline Parents' chengfen dummies & yes & yes \\
\hline \multicolumn{3}{|l|}{ Job characteristics } \\
\hline Occupation dummies & yes & yes \\
\hline City dummies & yes & yes \\
\hline Selectivity variable & $.411^{* * *}$ & \\
\hline Constant & $9.292^{* * *}$ & 2.182 \\
\hline Observations & 2,078 & 2,078 \\
\hline
\end{tabular}

Note: $*$ denotes the significance level, with ${ }^{* * *} \mathrm{p}<0.01, * * \mathrm{p}<0.05$, $* \mathrm{p}<0.1$. 


\subsection{Heckman Selection Model with Exclusion Restrictions}

The fact that nearly all the family background variables are statistically insignificant in the second stage in table 6 provides us with incentives and support to treat the family background variables more in an excluded restriction style.

Table 11 reports the estimates using family background variables as exclusion restrictions. Column 3 reports the marginal effects in the first stage probit model as usual (modelling selection into the state sector). Columns 1 and 2 report the estimates in the second step without family background variables included for the non-state and state sectors, respectively. Again, the estimates do not change much from the main results in tables 4 and 6.

\subsection{Cities with the Most Competitive Non-state Sector}

For regional considerations, we choose the cities where the private sector is the most competitive in terms of employment share to see whether the pattern will change in those cities.

The whole sample covers 77 cities in 12 provinces in China, with the employment share of state workers ranging from 39 percent to 98.6 percent. Among them, only 26 cities have the employment share of state workers below 70 percent. Compared to the other 51 cities, those 26 cities have a more competitive non-state sector. In this section, we use these 26 cities as our sample to see whether our results will be different in these cities. The employment share of state workers in each city is presented in table C2. Table 12 presents the estimates. The estimates do not change significantly, compared with the main results in tables 4 and 6 . 
Table 11: Heckman Two-step Estimates with Exclusion Restrictions

\begin{tabular}{|c|c|c|c|}
\hline & \multicolumn{2}{|c|}{ Second-step results } & \multirow{3}{*}{$\begin{array}{c}\text { First-step results } \\
{[3]} \\
\text { State }=1\end{array}$} \\
\hline & {$[1]$} & {$[2]$} & \\
\hline & Non-state & State & \\
\hline \multicolumn{4}{|l|}{ Individual demographics } \\
\hline Age & 0.00101 & $.0243^{* *}$ & 0.00396 \\
\hline Age squared & $-6.05 \mathrm{E}-05$ & $-.000326^{* *}$ & 0.000142 \\
\hline Male & $.194^{* * *}$ & $.111^{* * *}$ & -0.0104 \\
\hline Party membership & $.107^{* * *}$ & $.0887^{* * *}$ & $.230^{* * *}$ \\
\hline Minority ethnicity & 0.0784 & 0.0307 & 0.0485 \\
\hline Education & $.0310^{* * *}$ & $.0336^{* * *}$ & $.0409 * * *$ \\
\hline Experience & 0.00436 & 0.00175 & $-.447 * * *$ \\
\hline Tenure & 0.000315 & $.00490^{* * *}$ & \\
\hline \multicolumn{4}{|l|}{ Family background } \\
\hline Father alive & & & 0.0358 \\
\hline Mother alive & & & -0.0318 \\
\hline Father's age & & & 0.00343 \\
\hline Mother's age & & & $-.0297^{*}$ \\
\hline Father's age squared & & & $-3.06 \mathrm{E}-05$ \\
\hline Mother's age squared & & & $.000252^{* *}$ \\
\hline Father's party membership & & & $.165^{* * *}$ \\
\hline Mother's party membership & & & 0.0804 \\
\hline Father's education & & & 0.0823 \\
\hline Mother's education & & & $-.125^{* * *}$ \\
\hline Parents' chengfen dummies & & & yes \\
\hline \multicolumn{4}{|l|}{ Job characteristics } \\
\hline City dummies & yes & yes & yes \\
\hline Occupation dummies & yes & yes & yes \\
\hline Industry dummies & yes & yes & yes \\
\hline Selectivity variable & -0.0584 & $.127^{* * *}$ & \\
\hline Constant & $9.475^{* * *}$ & $8.642^{* * *}$ & $1.499^{*}$ \\
\hline Observations & 1,883 & 5,390 & 7,273 \\
\hline
\end{tabular}

Note: ${ }^{*}$ denotes the significance level, with ${ }^{* * *} \mathrm{p}<0.01,{ }^{* *} \mathrm{p}<0.05,{ }^{*} \mathrm{p}<0.1$. 
Table 12: Heckman Two-step Estimates for Cities with the Most Competitive Non-state Sector

\begin{tabular}{|c|c|c|}
\hline & $\begin{array}{c}{[1]} \\
\text { 2nd-step results }\end{array}$ & $\begin{array}{c}{[2]} \\
\text { 1st-step results } \\
\text { State }=1\end{array}$ \\
\hline \multicolumn{3}{|l|}{ Individual demographics } \\
\hline Age & -0.0413 & 0.0354 \\
\hline Age squared & 0.000488 & -0.000208 \\
\hline Male & $.0802^{* *}$ & 0.0425 \\
\hline Party membership & $.0756^{* *}$ & $.222^{* * *}$ \\
\hline Minority ethnicity & -0.0513 & -0.135 \\
\hline Education & $.0337^{* * *}$ & $.0472^{* * *}$ \\
\hline Experience & $.0246^{*}$ & $-.645^{* * *}$ \\
\hline Tenure & $.00711^{* * *}$ & \\
\hline \multicolumn{3}{|l|}{ Family background } \\
\hline Father alive & 0.00317 & 0.128 \\
\hline Mother alive & 0.0493 & -0.102 \\
\hline Father's age & 0.00944 & 0.0151 \\
\hline Mother's age & -0.0107 & $-.0436^{*}$ \\
\hline Father's age squared & $-6.54 \mathrm{E}-05$ & -0.00015 \\
\hline Mother's age squared & $8.11 \mathrm{E}-05$ & $.000369^{* *}$ \\
\hline Father's party membership & -0.00881 & $.171^{* *}$ \\
\hline Mother's party membership & -0.0101 & 0.137 \\
\hline Father's education & 0.0629 & 0.0838 \\
\hline Mother's education & 0.0287 & -0.0767 \\
\hline Parents' chengfen dummies & yes & yes \\
\hline \multicolumn{3}{|l|}{ Job characteristics } \\
\hline Occupation dummies & yes & yes \\
\hline Industry dummies & yes & yes \\
\hline Selectivity variable & $.291^{* * *}$ & \\
\hline Constant & $9.222^{* * *}$ & 0.267 \\
\hline Observations & 2,528 & 2,528 \\
\hline
\end{tabular}

Note: ${ }^{*}$ denotes the significance level, with ${ }^{* * *} \mathrm{p}<0.01,{ }^{* *} \mathrm{p}<0.05$, $* \mathrm{p}<0.1$. 


\section{Conclusion}

Using the CHIPs data, we examine the nature of labor mobility and expected earnings differentials between the state and non-state sector in urban China. We find that there is indeed a specific selection process in the state sector in that parents' characteristics affect their child's probability of being employed in the state sector. We also find significant earnings differentials between the state and non-state jobs. After controlling for individual characteristics, job-specific characteristics, and family background, workers in the state sector still significantly earn more than those working in the non-state sector. Generally, this is explained by state jobs being in better sectors and cities and attracting better workers in terms of human capital. While family background/networks do not have significant direct effects on earnings, they do have a significant indirect influence on earnings via the sector selection process.

The conventional wisdom on economic transition assumes an endogenous movement of workers away from the state into the non-state (private, individual, foreign) jobs. Yet we find the state still attracts the best workers in the more favorable sectors and regions in urban China in 2002. We take this as a sign that the private sector in the actual dualtrack of Chinese transition is underdeveloped in terms of offering an attractive package to workers. This is reinforced by the absence of a well-functioning social protection system. There is a structural earnings inequality between state and non-state sectors during this reform path which inhibits flows of workers and capital into the private sector.

In this paper, we have restricted our attention to analyzing earnings, which includes wages, bonus, allowances/subsidies, income in-kind, and such. Although many previous papers looked at wages, and the average wage in the state sector is indeed higher than in the non-state sector, we extend the focus a step further to include income in-kind, as this is also an important aspect of benefits associated with work. ${ }^{18}$ There are other aspects that also need to be considered, such as housing, pension, and health insurance. Nevertheless, since 1998 the welfare benefits of housing, pension, and health insurance have gradually been detached from employment in state jobs. In July 1998, the government announced

\footnotetext{
${ }^{18}$ See table C3 for details.
} 
that housing would no longer be a welfare benefit associated with work in the state jobs. In 1999, the government permitted the resale of housing units that were bought from state working unit. Both pension and health insurance are being detached from employment in state jobs. Those policies are expected to reduce the impact of those nonearning benefits associated with employment in state jobs on an individual's job choice and promote labor mobility. Hence, while our research is accurate up to the year 2002, one must be aware that after 2002, the transition process in China has entered into a new phase where the labor market has become more supportive of workers in the private sector. Yet, the preference for state jobs is still very evident in modern day national civil service examinations. 


\section{REFERENCES}

Adamchik, Vera A., and Arjun S Bedi. 2000. "Wage Differentials between the Public and the Private Sectors: Evidence from an Economy in Transition." Labour Economics, 7: 203-24.

Appleton, Simon; Lina Song, and Qingjie Xia. 2005. "Has China Crossed the River? The Evolution of Wage Structure in Urban China During Reform and Retrenchment." Journal of Comparative Economics, 33(4): 644-63.

Black, Sandra E., and Paul Devereux. 2010. "Recent Developments in Intergenerational Mobility." IZA working paper.

Blinder, Alan S. 1973. "Wage Discrimination: Reduced Form and Structural Estimates." The Journal of Human Resources, 8(4): 436-55.

Bourguignon, Francois, Francisco Ferreira, and Phillippe Leite. 2008. "Beyond OaxacaBlinder: Accounting for Differences in Household Income Distributions." Journal of Economic Inequality, 6(2): 117-48.

Burke, Fiona and Patrick Walsh. 2012. "Regional earning disparities and the speed of transition: evidence from Poland 1994-1997." IZA Journal of Labor and Development, 1(1): 1-19.

Calvo-Armengol, Antoni, and Matthew O. Jackson. 2004. "The Effects of Social Networks on Employment and Inequality." The American Economic Review, 94(3): 426-54.

Clapham, C., ed. 1982. Private Patronage and Public Power. London: Frances Pinter.

Cotton, J. 1988. "On the Decomposition of Wage Differentials." The Review of Economics and Statistics, 70: 236-43.

Currie, Janet, and Enrico Moretti. 2003. "Mother's Education and the Intergenerational Transmission of Human Capital: Evidence from College Openings." Quarterly Journal of Economics, 118(4): 1495-532.

Elder, Todd E., John H. Goddeeris, and Steven J. Haider. 2010. "Unexplained Gaps and Oaxaca Blinder Decompositions." Labour Economics, 17(1): 284-90.

Faccio, Mara. 2006. "Politically Connected Firms." The American Economic Review, 96(1): 369-86. 
Flinders, Matthew. 2009. "The Politics of Patronage in the United Kingdom: Shrinking Reach and Diluted Permeation." Governance, 22 (4): 547-70.

Freeman, Richard B., and James L. Medoff. 1981. "The Impact of the Percentage Organized on Union and Nonunion Wages." Review of Economics and Statistics, 63(4): $561-72$.

Glinskaya, Elena, and Michael Lokshin. 2005. "Wage Differentials between the Public and Private Sectors in India," World Bank Policy Research Working Paper 3574.

Gordin, Jorge P. 2002. "The Political and Partisan Determinants of Patronage in Latin America 1960-1994: A Comparative Perspective." European Journal of Political Research, 41:513-49.

Granovetter, Mark S. 1973. "The Strength of Weak Ties." American Journal of Sociology, 78(6): 1360-80.

Granovetter, Mark. 1995 Getting a Job: A Study of Contacts and Careers. Chicago: University of Chicago Press.

Griffin, Keith, and Renwei Zhao. 1993. The Distribution of Income in China. London: Macmillan and Co.

Haughton, Tim. 2008. "Parties, Patronage and the Post-Communist State." Comparative European Politics, 6 (4): 486-501.

Heckman, James J. 1979. "Sample Selection Bias as a Specification Error." Econometrica, 47(1): 153-61.

Hirsch, Barry T. and Edward J. Schumacher. 2002. "Match Bias In Wage Gap Estimates Due to Earnings Imputation." Journal of Labor Economics, 22 (3): 689-722.

Hunt, Allcott, Dean Karlan, Markus M. Mobius, Tanya S. Rosenblat, and Adam Szeidl. 2007. "Community Size and Network Closure." The American Economic Review, 97(2): 80-85.

Ioannides, Yannis M., and Adriaan R. Soetevent. 2006. "Wages and Employment in a Random Social Network with Arbitrary Degree Distribution." The American Economic Review, 96(2): 270-74.

Katz, Michael L., and Carl Shapiro. 1985. "Network Externalities, Competition, and 
Compatibility." The American Economic Review, 75(3): 424-40.

Lau, Lawrence J., Qian Yingyi, and Gerard Roland. 1997. "Pareto-improving economic reforms through dual-track liberalization." Economics Letters, 55: 285-292.

Lau, Lawrence J., Qian Yingyi, and Gerard Roland. 2000. "Reform without Losers: An Interpretation of China's Dual-Track Approach to Transition." Journal of Political Economy, 108(1): 120-143.

Lee, L. 1978. "Unionism and Wage Rates: A Simultaneous Equations Model with Qualitative Limited De pendent Variables." International Economic Review, 19: 415-33. Lewis, H. Gregg. 1963. Unionism and Relative Wages in the United States. Chicago: University of Chicago Press.

Li, Shi. 2008. Research on Income Distribution in China III. Beijing: Beijing Normal University Publishing Group.

Mayntz, Renate, and Hans-Ulrich Derlien. 1989. "Party Patronage and Politicization of the West German Administrative Elite 1970-1987 - Toward Hybridization?" Governance, 2(4): $384-404$.

Montgomery, James D. 1991. "Social Networks and Labor-Market Outcomes: Toward an Economic Analysis." The American Economic Review, 81(5): 1408-18.

Neumark, D. 1988. "Employers' Discriminatory Behavior and the Estimation of Wage Discrimination." The Journal of Human Resources, 23: 279-95.

Oaxaca, Ronald. 1973. "Male-Female Wage Differentials in Urban Labor Markets." International Economic Review, 14(3): 693-709.

Oaxaca, Ronald, and Michael R. Ransom, 1994. "On Discrimination and the Decomposition of Wage Differentials." Journal of Econometrics, 61: 5-21.

Oaxaca, Ronald L., and Michael R. Ransom, 1998. "Calculation of Approximate Variances for Wage Decomposition Differentials." Journal of Economic and Social Measurement, 24: $55-61$.

Oaxaca, Ronald L., and Michael R. Ransom. 1999. "Identification in Detailed Wage Decompositions." The Review of Economics and Statistics, 81: 154-57.

Opper, Sonja. 2001. "Dual-track Ownership Reforms: Lessons from Structural Change 
in China, 1978-1997." Post-Communist Economies, 13 (2): 206-27.

Rees, Albert. 1966. "Information Networks in Labor Markets," American Economic Review. 559-566.

Reimers, C. W. 1983. "Labor Market Discrimination against Hispanic and Black Men." The Review of Economics and Statistics, 65: 570-79.

Riskin, Carl, Renwei Zhao, and Shi Li. 2001. China's Retreat from Equality: Income Distribution and Economic Transition. New York: M.E. Sharpe, Armonk.

Solon, Gary. 2004. "A Model of Intergenerational Mobility Variation over Time and Place." In Generational Income Mobility in North America and Europe. Ed. Miles Corak, 38-47. Cambridge: Cambridge University Press.

Wu, Jinglian. 2009. "China's Economy: 60 Years of Progress," Caijing Magazine.

Xia, Q., L. Song, S. Li, and S. Appleton. 2013. "The Effects of the State Sector on Wage Inequality in Urban China: 1988-2007." China Growth Center Discussion Paper Series No.19. University of Oxford.

Yang, Dennis Tao. 1999. "Urban-Biased Policies and Rising Income Inequality in China." American Economic Review, 89(2): 306-10.

Zhao, Yaohui. 2002. "Earnings Differentials between State and Non-State Enterprises in Urban China." Pacific Economic Review, 2002, 7(1):181-9. 


\section{Appendix A: Data}

We construct the ownership variable based on the two following questions in the questionnaire:

1. Your current work unit is:

1) Enterprise;

2) Government agent;

3) Institution;

4) Others

2. If it is an enterprise, ownership of your present work unit is:

1) SOE at central/provincial level;

2) Local SOE;

3) Urban Collective;

4) Private firm (including partnership);

5) Self-employed;

6) Sino-foreign joint venture;

7) Foreign company;

8) State share-holding company;

9) Other share-holding company;

10) Others.

We categorize according to the following table: 
Table A.1: Construction of the State and Non-state Sectors

\begin{tabular}{lll}
\hline \hline Sector & \multicolumn{1}{c}{ Types of enterprises } & \multicolumn{1}{c}{ Categories in the questionnaire } \\
\hline \multirow{4}{*}{ State } & state-owned enterprises & 2.1 SOE at central/provincial level; \\
& & 2.2 Local SOE; \\
& government agents and institutions & 1.2 Government agent \\
& state share-holding enterprises & 1.3 Institution \\
& urban collective enterprises & 2.3 Urban Collective; \\
Non-state & private and individual enterprises & 2.4 Private firm (including partnership \\
& foreign-invested enterprises & 2.6 Sino-foreign joint venture; \\
& other share-holding enterprises & 2.7 Foreign company; \\
&
\end{tabular}

\section{Appendix B: Analysis on Waves 1988, 1995 and 2002}

Table B1 presents the descriptive statistics on employees' characteristics for both state and non-state jobs, indicating differences in individual characteristics and earnings between state and non-state jobs. ${ }^{19}$ Firstly, there are more male and more members of the communist party in the state jobs. Although there are still more male than female in both state and non-state sectors, the gap is decreasing. The proportion of communist party members is also increasing in both job types and there are more members in the state jobs.

Meanwhile, people tend to be older, more educated, more experienced, and have a longer tenure in the state jobs. The average age gap between the two sectors is $2-3$ years, and so is the experience. The tenure gap increased from 2 years in 1995 to about 5 years in 2002. As for the earnings, people in the non-state sector are likely to work longer but earn less.

Using repeated cross section OLS estimations, we present the results in table B2. In all the three waves, working in the state sector will significantly earn more than working in the non-state sector. Compared to 1988 and 1995, the coefficient of the ownership dummy variable decreased in 2002. After controlling for specific job characteristics and individual demographics, workers in the state sector still earn 8.6 oercent more than those who work in the non-state sector.

\footnotetext{
${ }^{19}$ For year 1988, instead of years of education, we only have data on education level. Furthermore, we do not have data on experience, tenure of current job, and working hours per year for this year.
} 
Table B.1: Descriptive Statistics in State and Non-state Jobs

\begin{tabular}{lllll}
\hline \hline & Year & 1988 & Year & 1995 \\
& State & Non-state & State & Non-sate \\
\hline \% of male & 56.4 & 38 & 55.5 & 40 \\
\% of CPC member & 27.8 & 9 & 27.7 & 11 \\
\% of minority ethnics & 3.8 & 3.6 & 4.4 & 4 \\
Average age (years) & 37.6 & 34.5 & 38.9 & 37.4 \\
Education (years) & & & 11 & 9.4 \\
Experience (years) & & & 19.9 & 16.5 \\
Tenure (years) & & & 15.4 & 13.7 \\
Earnings (yearly, RMB) & 178 & \multirow{2}{*}{155} & 6,371 & 4,972 \\
Working hours (yearly) & & & 2,183 & 2,273 \\
Earnings per hour (RMB) & & & 3.1 & 2.4 \\
Observations & 10,555 & 6,906 & 11,469 & 2,078 \\
\hline
\end{tabular}

Note: CPC stands for Communist Party of China. Here, experience is measured by "years of being employed". These are all nominal earnings. Since we focus on the earnings differentials between state and non-state sectors within each year, there is no need to deflate it.

Table B.2: OLS Estimates for the Conventional Earning Equation

\begin{tabular}{lccc}
\hline \hline Y=Log(annual earnings) & 1988 & 1995 & 2002 \\
\hline Ownership type & & & \\
State sector & $.116^{* * *}$ & $.197^{* * *}$ & $.0855^{* * *}$ \\
\hline Individual demographics & & & \\
Age & $.0782^{* * *}$ & $.0871^{* * *}$ & $.0547^{* * *}$ \\
Age squared & $-.000803^{* * *}$ & $-.00121^{* * *}$ & $-.000653^{* * *}$ \\
Male & $.108^{* * *}$ & $.151^{* * *}$ & $.117^{* * *}$ \\
Party membership & $.0635^{* * *}$ & $.101^{* * *}$ & $.0971^{* * *}$ \\
Minority Ethnicity & -0.00901 & -0.0457 & 0.042 \\
Education & & $.0184^{* * *}$ & $.0334^{* * *}$ \\
Tenure & & -0.000251 & $.00368^{* * *}$ \\
Experience & & $.0222^{* * *}$ & $.0108^{* * *}$ \\
Experience squared & & -0.00014 & -0.000111 \\
\hline Job characteristics & & & \\
City dummies & yes & yes & yes \\
Occupation dummies & yes & yes & yes \\
Industry dummies & yes & yes & yes \\
Constant & $3.380^{* * *}$ & $6.553^{* * *}$ & $7.925^{* * *}$ \\
Observations & 16,973 & 10,806 & 8,925 \\
R-squared & 0.37 & 0.339 & 0.433 \\
\hline
\end{tabular}

Note:* denotes the significance level, with ${ }^{* * *} \mathrm{p}<0.01$, ** $\mathrm{p}<0.05,{ }^{*}$ $\mathrm{p}<0.1$. For year 1995 and 2002, the education variable both means "years of schooling". But for year 1988, we only have data on education level. So, in the regression for year 1988, we use education level to create education dummy variables. We did not report it here, but it turns out that the higher education level you get, the more you earn. For round 1988, we used dummies for province instead of cities. 
As for the socio-economic characteristics, firstly, both age and its square term are significant in three rounds, but the coefficient is positive of the age term and the coefficient is negative for the age squared term. Individuals' earnings may increase as the age increases, but the marginal increase is diminishing.

While the minority ethnicity variable stays insignificant from 1988 to 2002, the gender dummy and party membership dummy stay significant throughout, with a positive coefficient. ${ }^{20}$ Males tend to earn 11-15 percent more than females. And being a member of the Communist Party of China is associated with 6-10 percent higher earnings. Education and experience play a significantly positive role for higher earnings, while tenure of current job became significant with positive coefficients in 2002.

These findings are in accordance with previous literature. After controlling for jobspecific and individual-specific characteristics, there are still significant earnings differentials between the state and non-state jobs in the urban labor market in China. Individual demographics and job specific characteristics are essential in determining these differentials. From 1988 to 2002, the rewarding system in urban China stays quite persistent.

\section{Appendix C: Additional Ananlysis on Earnings(Wage) Distribution}

Figure $\mathrm{C} 1$ provides information on the earnings and wage distribution in state and non-state jobs for the year 2002, respectively. Figure C2 and C3 depict the earnings distribution in various industries and provinces.Figure C4 shows the shares of state workers in each industry. Table $\mathrm{C} 1$ reports the number of observations in 15 industries, while table $\mathrm{C} 2$ shows the employment share of state workers in each city. Last but not least, table C3 provides detailed earnings in state and non-state jobs.

\footnotetext{
${ }^{20}$ Here, the party membership refers to membership of the Communist Party of China.
} 

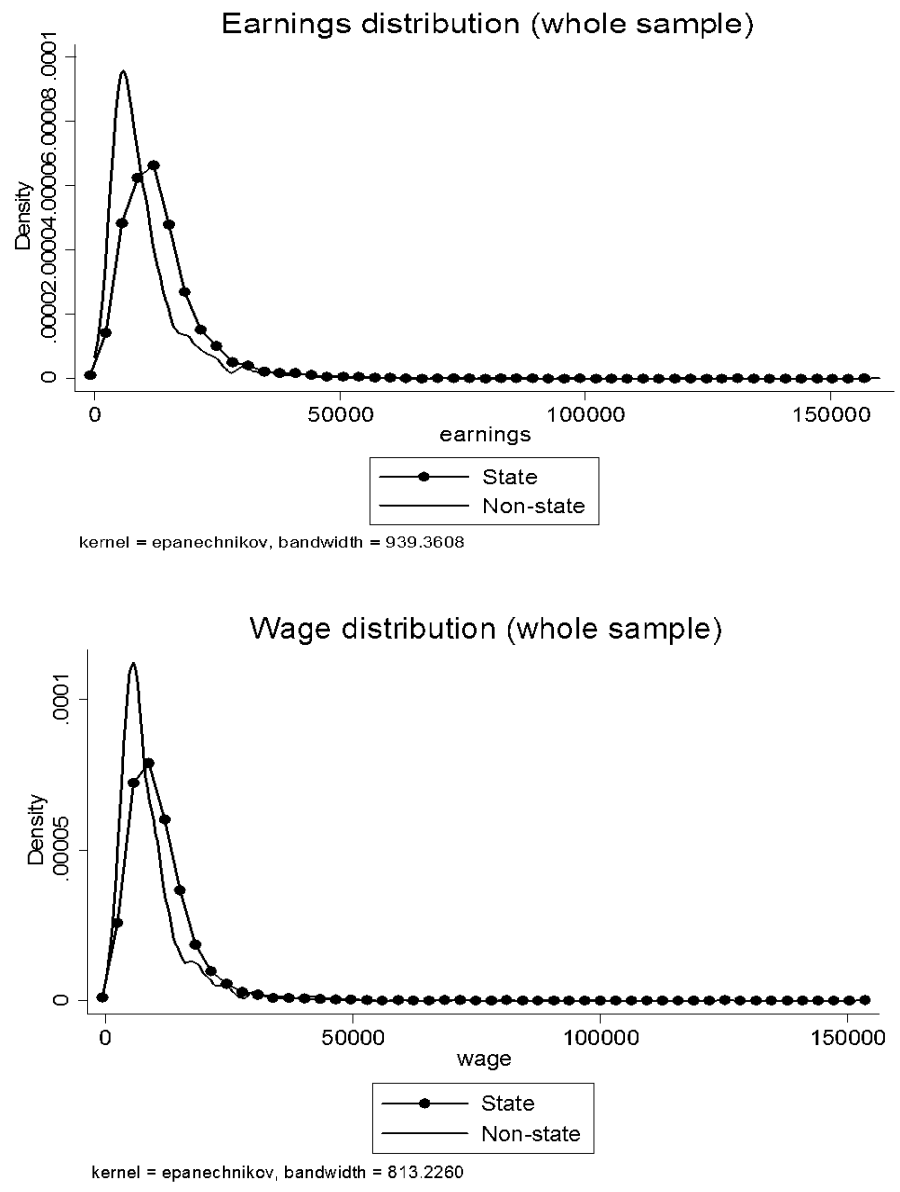

Figure C.1: Earnings (Wage) Distribution in the State and Non-state Jobs 


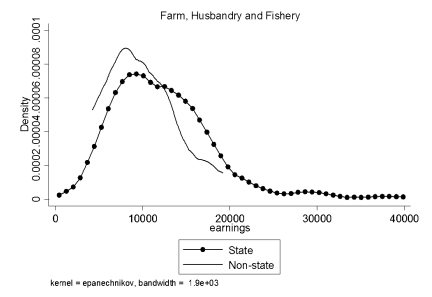

(a) Farm, Husbandary and Fishery

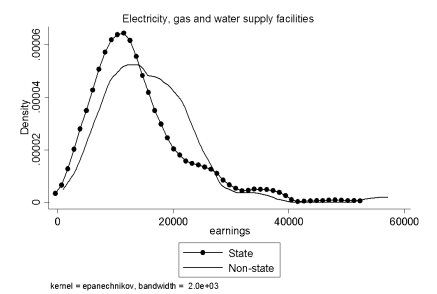
(d) Electricity, gas, water supply
facilities

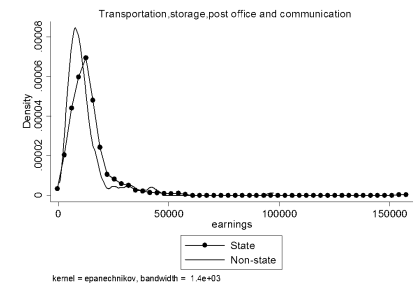

(g) Transportation, storage, post office and communication

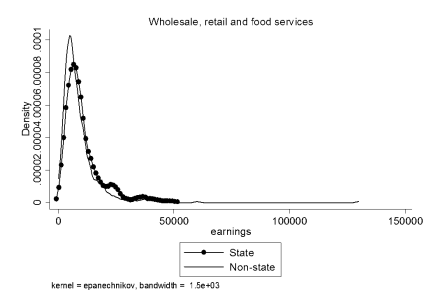

(j) Wholesale, retail and food service

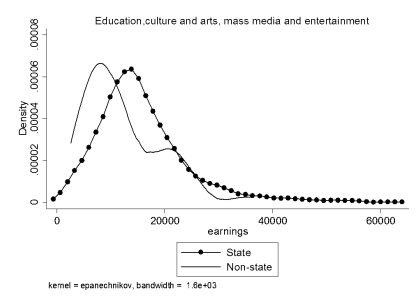

(m) Education, culture and arts, mass media and entertainment

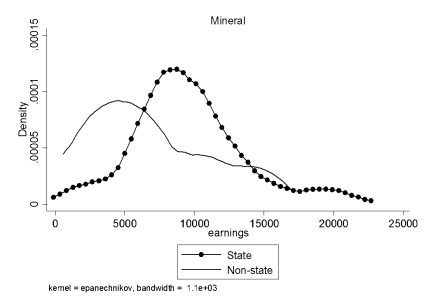

(b) Mineral

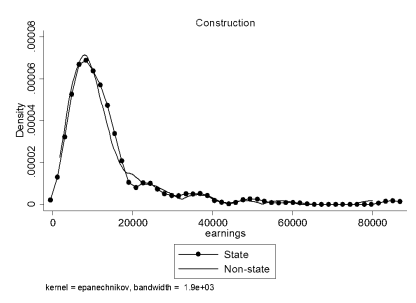

(e) Construction

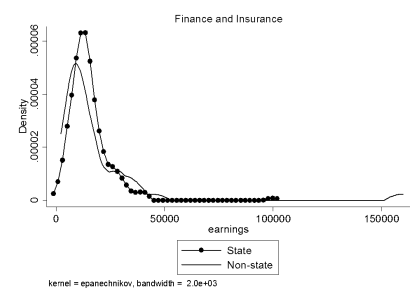

(h) Finance and insurance

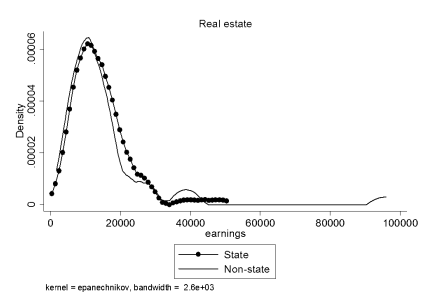

(k) Real estate

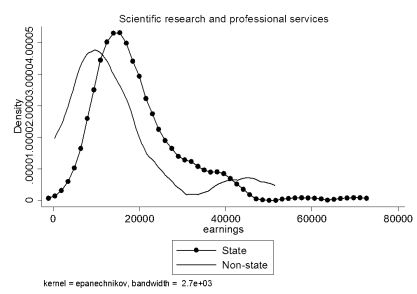

(n) Scientific research and professional services

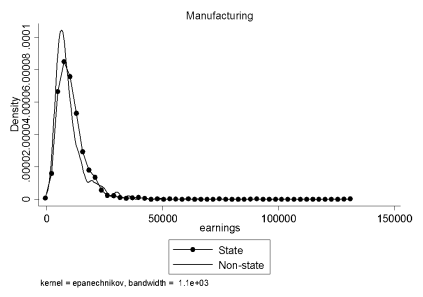

(c) Manufacturing

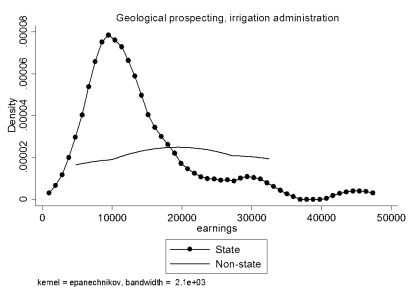

(f) Geological prospecting, irrigation administration

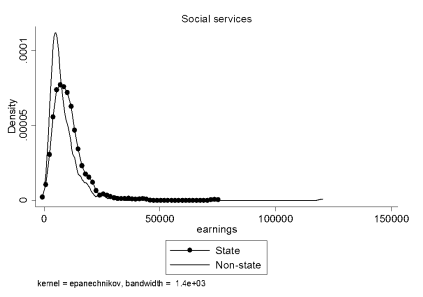

(i) Social service

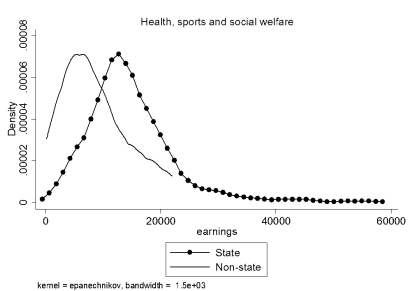

(1) Health, sports and social welfare

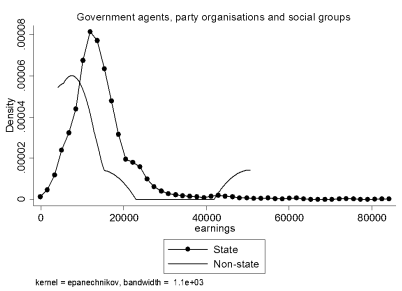

(o) Government agents, party orgnisations and social groups

Figure C.2: Earnings Distribution in Different Industries 
Table C.1: Number of Observations in 15 Industries

\begin{tabular}{|c|c|c|c|}
\hline & Total & State & Non-state \\
\hline $\begin{array}{l}\text { Farm, forest, } \\
\text { husbandry and fishery }\end{array}$ & 104 & 92 & 11 \\
\hline Mineral & 130 & 114 & 16 \\
\hline Manufacturing & 2112 & 1236 & 854 \\
\hline $\begin{array}{l}\text { Electricity, gas and } \\
\text { water supply facilities }\end{array}$ & 260 & 206 & 54 \\
\hline Construction & 255 & 176 & 73 \\
\hline $\begin{array}{l}\text { Geological prospecting, } \\
\text { irrigation administration }\end{array}$ & 74 & 73 & 1 \\
\hline $\begin{array}{l}\text { Transportation, storage, } \\
\text { post office and communication }\end{array}$ & 571 & 445 & 119 \\
\hline $\begin{array}{l}\text { Wholesale, retail and } \\
\text { food services }\end{array}$ & 655 & 267 & 366 \\
\hline Finance and insurance & 204 & 174 & 24 \\
\hline Real estate & 91 & 60 & 31 \\
\hline Social services & 671 & 339 & 243 \\
\hline $\begin{array}{l}\text { Health, sports and } \\
\text { social welfare }\end{array}$ & 416 & 390 & 21 \\
\hline $\begin{array}{l}\text { Education, culture and arts, } \\
\text { mass media and entertainment }\end{array}$ & 724 & 698 & 22 \\
\hline $\begin{array}{l}\text { Scientific research and } \\
\text { professional services }\end{array}$ & 143 & 137 & 6 \\
\hline $\begin{array}{l}\text { Government agents, party } \\
\text { organizations and social groups }\end{array}$ & 992 & 975 & 4 \\
\hline
\end{tabular}




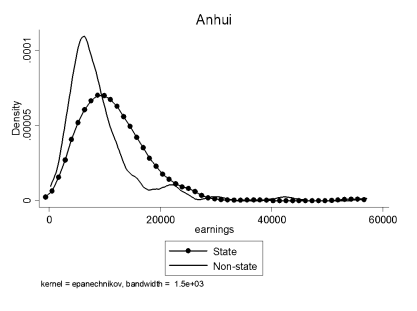

(a) Anhui

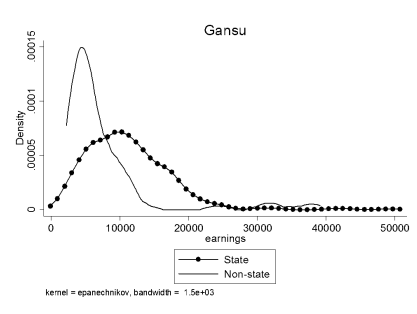

(d) Gansu

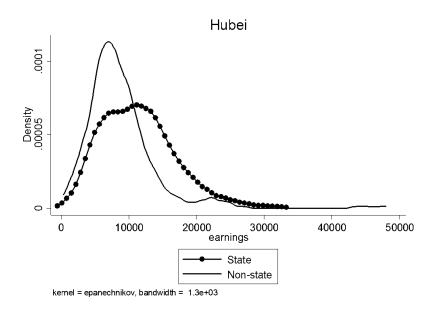

(g) Hubei

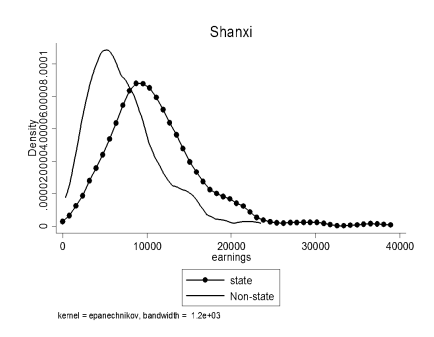

(j) Shanxi

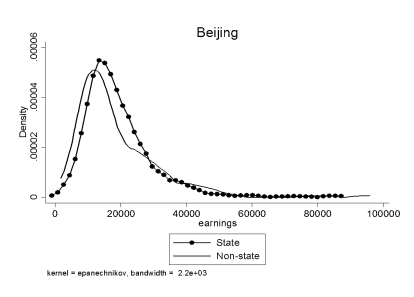

(b) Beijing

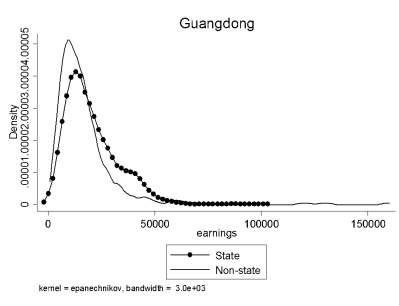

(e) Guangdong

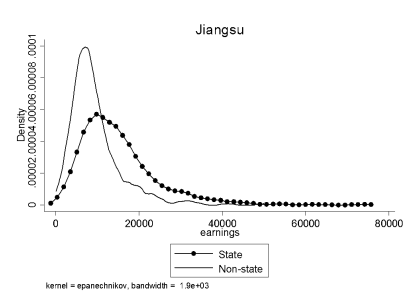

(h) Jiangsu

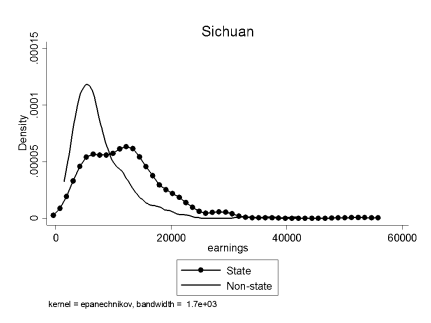

(k) Sichuan

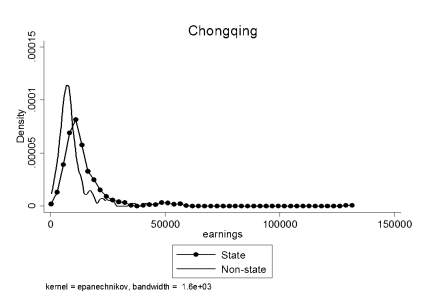

(c) Chongqing

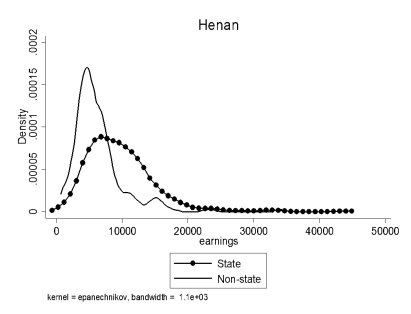

(f) Henan

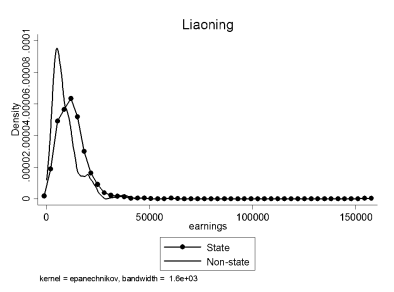

(i) Liaoning

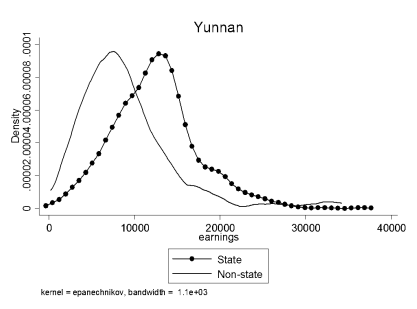

(1) Yunnan

Figure C.3: Earnings Distribution in Different Provinces 


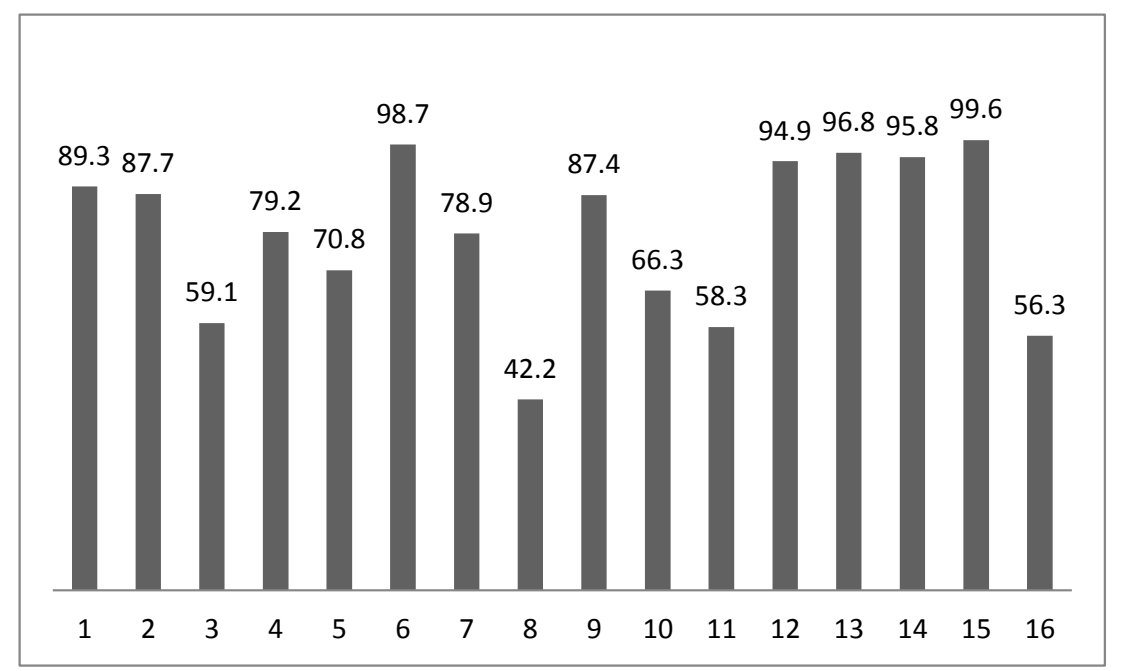

Figure C.4: Share of State Workers in Each Industry (\%)

Note: 1:Farm, forest, husbandry and fishery;2:Mineral; 3:Manufacturing; 4: Electricity, gas and water supply facilities; 5: Construction; 6: Geological prospecting, irrigation administration; 7: Transportation, storage, post office and communication; 8: Wholesale, retail and food services; 9: Finance and insurance; 10: Real estate; 11: Social services; 12: Health, sports and social welfare; 13: Education, culture and arts, mass media and entertainment; 14: Scientific research and professional services; 15: Government agents, party organizations and social groups. 
Table C.2: Employment Share of State Workers in Each City (\%)

\begin{tabular}{llll}
\hline \hline City Code & $\%$ & City Code & $\%$ \\
\hline 110101 & 83.82 & 410526 & 68.42 \\
110102 & 77.24 & 410700 & 76.15 \\
110103 & 64.44 & 410782 & 63.33 \\
110104 & 80 & 411025 & 81.25 \\
110105 & 85.12 & 411525 & 88.46 \\
110106 & 81.82 & 420100 & 79.31 \\
110107 & 82.35 & 420500 & 90.51 \\
110108 & 80.68 & 420600 & 84.06 \\
140100 & 87.39 & 421000 & 47.5 \\
140200 & 84.16 & 421083 & 76.19 \\
140225 & 78.26 & 421125 & 76.56 \\
140400 & 81.19 & 421200 & 76.79 \\
140800 & 84.85 & 440100 & 72.62 \\
142303 & 72.92 & 440200 & 80.95 \\
142325 & 98.57 & 440600 & 51.85 \\
210100 & 65.59 & 440681 & 39.39 \\
210200 & 57.96 & 440800 & 65 \\
210281 & 52.54 & 441200 & 85.25 \\
210700 & 83.06 & 441300 & 69.35 \\
211224 & 75 & 445281 & 68.12 \\
320100 & 77.42 & 500100 & 78.13 \\
320200 & 58.33 & 500101 & 60 \\
320282 & 40.63 & 510100 & 69.89 \\
320300 & 80.18 & 510500 & 66.92 \\
320600 & 39.51 & 510800 & 64.34 \\
320982 & 44.44 & 511000 & 60 \\
321000 & 80 & 511181 & 60.47 \\
321283 & 58.33 & 511300 & 60.71 \\
321300 & 52.5 & 530100 & 71.96 \\
340100 & 70.49 & 530200 & 81.73 \\
340200 & 56.1 & 530381 & 90.14 \\
340300 & 58 & 530500 & 91.82 \\
340400 & 91.27 & 532501 & 63.74 \\
341021 & 70.97 & 532722 & 84 \\
341600 & 90.91 & 532901 & 79.41 \\
410100 & 81.63 & 533221 & 90.91 \\
410200 & 79.01 & 620100 & 89.74 \\
410400 & 90.83 & 622301 & 75.73 \\
& & 622701 & 89.26 \\
\hline
\end{tabular}


Table C.3: Detailed Earnings in the State and Non-state Jobs

\begin{tabular}{lll}
\hline \hline & State & Non-state \\
\hline Average earnings (yearly, RMB) & 13,308 & 10,284 \\
Of which: wages (yearly, RMB) & 10,612 & 8,950 \\
Of Which: Bonus(yearly, RMB) & 1,331 & 7,44 \\
Of which: Allowances/Subsidies (yearly, RMB) & 940 & 252 \\
Of which: Income in-kind (yearly, RMB) & 132 & 154 \\
\hline
\end{tabular}

